Results: We studied 100 patients/180 affected eyes (54M/46W), mean age $40.7 \pm 10.1$. The ocular pattern was panuveitis $(n=62)$, posterior (27) and anterior uveitis (11). Before IFX they received iv MP (28), cyclosporine (75), azathioprine (56), metotrexate (43) and others (33). IFX dose ranged between $3-5 \mathrm{mg} / \mathrm{kg} / 4$ or 8 weeks. In patients in remission IFX was optimized $(n=28)$ or stopped $(n=20)$.

\begin{tabular}{|c|c|c|c|c|c|c|c|c|c|}
\hline & Baseline & $1^{5 t_{\text {week }}}$ & $\begin{array}{l}1^{\text {th }} \\
\text { month }\end{array}$ & $\begin{array}{l}3^{\text {th }} \\
\text { month }\end{array}$ & $\begin{array}{l}6^{\text {th }} \\
\text { month }\end{array}$ & $\begin{array}{l}1^{\text {st }} \\
\text { year }\end{array}$ & $\begin{array}{l}2^{\text {nd }} \\
\text { year }\end{array}$ & $\begin{array}{l}3^{\text {th }} \\
\text { year }\end{array}$ & $\begin{array}{l}4^{\text {th }} \\
\text { year }\end{array}$ \\
\hline $\begin{array}{l}\text { va } \\
\text { (meantSD) }\end{array}$ & $\begin{array}{l}\begin{array}{l}0.5 \pm 0.35 \\
n=193\end{array} \\
n=193\end{array}$ & $\begin{array}{l}0.5 \pm 0.3^{*} \\
n=189\end{array}$ & $\begin{array}{l}\begin{array}{l}0.6 \pm 0.3^{*} \\
n=187^{2}\end{array} \\
n=1\end{array}$ & $\begin{array}{c}0.6 \pm 0.3^{*} \\
n=183\end{array}$ & $\begin{array}{l}0.5 \pm 0.3 \\
\vdots=176\end{array}$ & $\begin{array}{l}0.650 .3 \\
n=159\end{array}$ & $\begin{array}{l}0.5 \pm 0.3 \\
n=130 \\
n=130\end{array}$ & $\begin{array}{l}0.550 .3 \\
n=88\end{array}$ & $\begin{array}{l}0.7+0.3^{*} \\
n=60 \\
n=0\end{array}$ \\
\hline $\begin{array}{l}\text { Cells in the } \\
\text { anterior } \\
\text { chamber } \\
\text { (median } \\
\text { [IQR]) }\end{array}$ & $\begin{array}{l}1[0.2] \\
n=190\end{array}$ & $\begin{array}{l}0[0-1]^{*} \\
n=187\end{array}$ & $\begin{array}{l}O(0.0)^{*} \\
n=184\end{array}$ & $\begin{array}{l}0[0-0)^{*} \\
n=180\end{array}$ & $\begin{array}{l}0[0-0]^{*} \\
n=171\end{array}$ & $\begin{array}{l}0[0.00 * \\
n=153\end{array}$ & $\begin{array}{l}0\left[0.00 x^{*}\right. \\
n=126\end{array}$ & $\begin{array}{l}0[0.00 * \\
n=82\end{array}$ & $\begin{array}{l}0[0-0]^{*} \\
n=58\end{array}$ \\
\hline $\begin{array}{l}\text { vitritisis } \\
\text { (median } \\
\text { (IQRRI) }\end{array}$ & $\begin{array}{l}1[0-2 \\
n=188\end{array}$ & 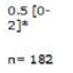 & $\begin{array}{l}o[0-0]^{*} \\
n=182\end{array}$ & $\begin{array}{l}0[0-0]^{*} \\
n=177\end{array}$ & $\begin{array}{l}0[0-0]^{*} \\
n=168\end{array}$ & $\begin{array}{l}0[0-0]^{*} \\
n=149\end{array}$ & $\begin{array}{l}0[0-0]^{*} \\
n=122\end{array}$ & $\begin{array}{l}0[0-0]^{*} \\
n=84\end{array}$ & $\begin{array}{l}0[0-0]^{*} \\
n=58\end{array}$ \\
\hline 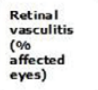 & $\begin{array}{l}53.4 \% \\
n=188\end{array}$ & $\begin{array}{l}43.1 \% \\
n=183\end{array}$ & $\begin{array}{l}22.2 \% \\
n=183\end{array}$ & $\begin{array}{l}10.9 \% \\
n=177\end{array}$ & $\begin{array}{l}7.4 \% \\
n=171\end{array}$ & $\begin{array}{l}2.4 \% \\
n=153\end{array}$ & $\begin{array}{l}1.9 \% \\
n=124\end{array}$ & $\begin{array}{l}0.4 \% \\
n=84\end{array}$ & $\begin{array}{l}0.4 \% \\
n=54\end{array}$ \\
\hline $\begin{array}{l}\text { OCr (u) } \\
\text { (meantso) }\end{array}$ & $\begin{array}{l}331.5 \neq \\
136.1 \\
n=59\end{array}$ & $\begin{array}{l}\begin{array}{l}324 \pm \\
123.8^{*} \\
n=53\end{array} \\
n=5\end{array}$ & $\begin{array}{l}298.7 \pm 101 \\
.8^{*} \\
n=53\end{array}$ & $\begin{array}{l}283.2 \pm 83 . \\
6^{*}=49 \\
n=49\end{array}$ & $\begin{array}{l}265.8 \pm 6 \\
6.5{ }^{*} \\
n=42\end{array}$ & $\begin{array}{l}\begin{array}{l}264.1 \\
\pm 6.133^{*} \\
n=46\end{array} \\
n=4\end{array}$ & $\begin{array}{l}\begin{array}{l}263.6 \\
\pm 552^{*} \\
n=27\end{array} \\
n=27\end{array}$ & $\begin{array}{l}239.8 \pm \\
25.8^{2 .} \\
n=14\end{array}$ & $\begin{array}{l}231.2 \pm 3 \\
5.7^{*} \\
n=8\end{array}$ \\
\hline
\end{tabular}

Conclusions: IFX is an effective long term-treatment in refractory Uveitis of BD. Optimization and even discontinuation of IFX after remission is possible.

Disclosure of Interest: None declared

DOI: 10.1136/annrheumdis-2017-eular.6226

\section{FRI0608 STUDY OF ARTICULAR SARCOIDOSIS IN A TERTIARY CARE HOSPITAL}

M. Garijo Bufort ${ }^{1}$, E. Vallejo Pascual ${ }^{2}$, C. Moriano Morales ${ }^{1}$, M. Retuerto Guerrero $^{1}$, C. Iñiguez Ubiaga ${ }^{1}$, A. Crespo Golmar ${ }^{1}$, A. López Robles ${ }^{1}$, C. Álvarez Castro ${ }^{2}$, E. Diez Álvarez ${ }^{1}$, M. Martín Martínez ${ }^{1}$, T. Pérez Sandoval ${ }^{2}$ ${ }^{1}$ Rheumatology Department of the University Health Care Complex of León; ${ }^{2}$ University of Leon, León, Spain

Background: Sarcoidosis is a systemic granulomatous disease, being the joint involvement a poorly studied manifestation.

Objectives: To describe the clinical and demographic characteristics of patients with sarcoidosis, paying particular attention to the joint involvement and its possible relationship with other extra-articular manifestations, as well as the treatment recieved.

Methods: A retrospective, observational study that included 104 patients who were admitted to the Hospital of León between January 2011 and December 2015 with main or secondary diagnosis of sarcoidosis; according to clinical onset, imaging tests and/or anatomopathological study. The variables studied were: age at the time of diagnosis, sex, type of joint involvement, forms of extra-articular involvement, serologic parameters and drugs received. Statistical analysis was performed using SPSSv22.0, $p<0.005$.

Results: $57.7 \%$ of the patients included in the study were women with a mean age of $53.42 \pm 18.4$ years. At the systemic level, $35 \%$ of them presented fever, $66.3 \%$ lymphadenopathy and $4.8 \%$ splenomegaly. $97.1 \%$ of the patients presented pulmonary involvement, with stage II being the most common (46.2\%). Only 8 patients had cardiac abnormalities. Ocular involvement was observed in $10.6 \%$, predominating uveitis. The most common renal manifestation was hypercalciuria in $6.7 \%$. The presence of neurological involvement was exceptional, detecting 3 cases of neurosarcoidosis. In the cutaneous involvement $(2.9 \%)$, erythema nodosum predominated $(17.3 \%)$. The CRP levels were normal in $44.3 \%(<5 \mathrm{mg} / \mathrm{dl})$ and high levels of CRP were found in $25.3 \%$ of the sample ( $>30 \mathrm{mg} / \mathrm{dl}$ ). $62.6 \%$ presented pathological figures of ACE. The joint involvement was present in $38.5 \%$ of the patients $(14.4 \%$ in the form of arthralgia, $2.9 \%$ as periarthritis, $13.5 \%$ as acute arthritis, $4.8 \%$ as chronic arthritis and $2.9 \%$ as sacroilitis). The $19,23 \%$ debuted as Löefgren syndrome, being seen an association between the presence of acute arthritis and erythema nodosum $(p 0,000)$. The mean age observed in patients with acute arthritis was lower than the one of the other patients with other joint manifestations $(p 0.044)$ and a statistically significant relationship was observed between the absence of joint and ocular involvement $(\mathrm{p} 0,011)$. Regarding the treatment of joint manifestations, $30.77 \%$ of the cases were resolved with NSAIDs, $46.15 \%$ with corticosteroids in a monotherapy and $15.38 \%$ required an immunosuppressant. In our study, most patients treated with corticosteroids did not show articular nor ocular involvement ( $p 0,018)$, although when analysing the ocular involvement separately, many received corticoid treatment $(42.86 \%)$. Only one patient required Adalimumab for refractory uveitis and another presented anti-TNF $\alpha$-induced sarcoidosis (Infliximab).

Conclusions: The pulmonary involvement is the predominant one in patients with sarcoidosis. The acute arthritis occurs in younger patients and is associated with the onset of erythema nodosum. The joint involvement is usually not severe and, although it has not been demonstrated, it seems that the use of corticosteroids predominates in the extra-articular manifestations. Only 1 in 4 patients showed an increase of acute phase reactants.

Disclosure of Interest: None declared

DOI: 10.1136/annrheumdis-2017-eular.6674

\section{FRI0609 USEFULNESS OF FDG-PET/CT IMAGING AND SEROLOGICAL BIOMARKERS TO PREDICT RELAPSE IN IGG4-RELATED DISEASE}

M. Kato, H. Ozaki, T. Kameda, M. Izumikawa, S. Nakashima, H. Shimada, R. Wakiya, A. Kondo, N. Kadowaki, H. Dobashi. Department of Internal Medicine, Division of Hematology, Rheumatology and Respiratory Medicine, Faculty of Medicine, Kagawa University, Kita-gun, Japan

Background: IgG4-RD shows relapses frequently. It is important to search to the factors to predict relapse. Recent research has shown the usefulness of FDG-PET/CT for IgG4-RD because it is more sensitive than conventional imaging to detect organ involvement of the disease. It has been suggested that FDG-PET/CT is also useful for monitoring therapeutic response of IgG4-RD.

Objectives: We investigate the usefulness of FDG-PET/CT imaging and serological biomarkers to predict relapse in IgG4-RD.

Methods: We analyzed 24 patients with IgG4-RD treated for more than 1 year between 2008 and 2016 in our facility. The diagnosis for IgG4-RD was based on comprehensive diagnostic criteria for IgG4-RD. All cases underwent FDG-PET/CT at least once, and laboratory data were collected from their medical records retrospectively. Levels of serum C-reactive protein (CRP), eosinophil/leukocyte ratio, serum IgG, IgG4, IgA, IgM, IgE, slL2-R and serum compliment were investigated.

Results: The patients had a mean age of 67.9 years (range: $50-87$ years). In the cases with high FDG uptake on FDG-PET/CT, they had a greater number of organ involvements, higher serum IgG and sIL-2R levels. Eight patients experienced relapses following treatment. Higher serum IgG predicted relapses of IgG4-RD. FDG-PET/CT findings at baseline were not associated with relapse. FDG-PET/CT was performed in 13 patients after initiation of treatment and 4 patients had a relapse. There were no significant reduction of abnormal FDG uptake in 6 patients, and 4 of 6 patients relapsed.

Conclusions: In this study, we examined the factors to predict relapse in IgG4-RD. Patients with higher serum IgG were regarded as a risk of relapse, but FDG-PET/CT findings at baseline were not associated with relapse. FDG-PET/CT reexamined after initiation of treatment is useful to predict relapse of IgG4-RD.

\section{References:}

[1] Umehara H, Okazaki K, Masaki Y, et al. Comprehensive diagnostic criteria for IgG4-related disease (IgG4-RD), 2011. Mod Rheumatol. 2012 Feb;22(1):2130.

[2] Nakatani K. Utility of FDG PET/CT in IgG4-related systemic disease Clin Radiol. 2012 Apr;67(4):297-305.

[3] Zhang J, Chen $\mathrm{H}$, Ma Y, et al. Characterizing IgG4-related disease with 18F-FDG PET/CT: a prospective cohort study. Eur J. Nucl Med Mol Imaging. 2014;41:1624-1634.

Disclosure of Interest: None declared

DOI: 10.1136/annrheumdis-2017-eular.5648

\section{FRI0610 PROBLEMS IN THE DIAGNOSIS OF FAMILIAL MEDITERRANEAN FEVER IN TURKEY}

M. Erdoğan, Y. Özgüler, G. Karatemiz, S.N. Esatoğlu, G. Güzelant, E. Dinçes, S. Uğurlu, G. Hatemi, H. Özdoğan, E. Seyahi. Internal Medicine, Division of Rheumatology, Cerrahpaşa Medical Faculty, University of Istanbul, Istanbil, Turkey

Background: The diagnosis of FMF (Familial Mediterranean Fever) can be missed or delayed even in a country like Turkey, one of the most prevalent places for FMF (1).

Objectives: We compared the duration of delay in diagnosis before and after year 2000, and assessed the problems related with the diagnosis of FMF.

Methods: We studied $143(102 \mathrm{~F}, 41 \mathrm{M})$ consecutive patients with FMF seen at the rheumatology outpatient clinic, between November 2016 and January 2017. Patients completed a self-administered questionnaire that assesses initial symptoms, previous diagnosis and treatments received before the formal diagnosis of FMF. Patients were divided in 2: as Group 1, which includes 70 patients seen for the first time by a physician before 2000 and Group 2, which includes 73 patients seen after 2000 .

Results: The median age of the patients was 34 years [IQR:27-45]. The F/M ratio was 2.4. The initial symptom was abdominal pain in the majority $(n=134$, $89 \%)$, followed by fever $(n=114,75 \%)$, arthritis $(n=66,44 \%)$, pleuritic pain $(n=21$, $14 \%)$, arthralgia $(n=11,7 \%)$ and other complaints $(n=14,9 \%)$.

The median age at initial symptom was 10 years (IQR:6-23). The median delay in diagnosis was 8 years [IQR:2-15]. This was significantly shorter in Group 2 (median: 4 years [IQR:0-11]) than that observed in Group 1 (median: 10 years [IQR:6-17]), as shown in Table.

A total of 110 patients $(73 \%)$ were diagnosed with one or more diseases or syndromes other than FMF. These were appendicitis ( $n=50,45 \%)$, gastrointestinal diseases $(n=44,40 \%)$, acute rheumatic fever $(n=36,33 \%)$, inflammatory 